\title{
Irrigation and Fertigation with Drip and Alternative Micro Irrigation Systems in Northern Highbush Blueberry
}

\author{
Oscar L. Vargas ${ }^{1}$ \\ Department of Horticulture, Oregon State University, 4017 ALS, Corvallis, \\ OR 97331
}

\author{
David R. Bryla ${ }^{2}$ and Jerry E. Weiland \\ U.S. Department of Agriculture, Agricultural Research Service, Horti- \\ cultural Crops Research Unit, 3420 NW Orchard Avenue, Corvallis, \\ OR 97330
}

\author{
Bernadine C. Strik \\ Department of Horticulture, Oregon State University, 4017 ALS, Corvallis, \\ OR 97331
}

\section{Luna Sun \\ Department of Statistics, Oregon State University, 44 Kidder Hall, Corvallis, OR 97331}

Additional index words. Vaccinium corymbosum, Phytophthora cinnamomi, geotextile irrigation system, microsprinklers, nutrient management, root rot

\begin{abstract}
The use of conventional drip and alternative micro irrigation systems were evaluated for 3 years in six newly planted cultivars (Earliblue, Duke, Draper, Bluecrop, Elliott, and Aurora) of northern highbush blueberry (Vaccinium corymbosum L.). The drip system included two lines of tubing on each side of the row with in-line drip emitters at every $0.45 \mathrm{~m}$. The alternative systems included geotextile tape and microsprinklers. The geotextile tape was placed alongside the plants and dispersed water and nutrients over the entire length. Microsprinklers were installed between every other plant at a height of $1.2 \mathrm{~m}$. Nitrogen was applied by fertigation at annual rates of 100 and $200 \mathrm{~kg} \cdot \mathrm{ha}^{-1} \mathrm{~N}$ by drip, $200 \mathrm{~kg} \cdot \mathrm{ha}^{-1} \mathrm{~N}$ by geotextile tape, and $280 \mathrm{~kg} \cdot \mathrm{ha}^{-1} \mathrm{~N}$ by microsprinklers. By the end of the first season, plant size, in terms of canopy cover, was greatest with geotextile tape, on average, and lowest with microsprinklers or drip at the lower $\mathbf{N}$ rate. The following year, canopy cover was similar with geotextile tape and drip at the higher $\mathrm{N}$ rate in each cultivar, and was lowest with microsprinklers in all but 'Draper'. In most of the cultivars, geotextile tape and drip at the higher $\mathrm{N}$ rate resulted in greater leaf $\mathbf{N}$ concentrations than microsprinklers or drip at the lower $\mathbf{N}$ rate, particularly during the first year after planting. By the third year, yield averaged 3.1-9.1 $\mathrm{t} \cdot \mathrm{ha}^{-1}$ among the cultivars, but was similar with geotextile tape and drip at either $N$ rate, and was only lower with microsprinklers. Overall, drip was more cost effective than geotextile tape, and fertigation with $100 \mathrm{~kg} \cdot \mathrm{ha}^{-1} \mathrm{~N}$ by drip was sufficient to maximize early fruit production in each cultivar. Microsprinklers were less effective by comparison and resulted in white salt deposits on the fruit.
\end{abstract}

Until recently, most blueberry fields in the United States were irrigated with sprinklers. However, many new plantings are irrigated by drip, particularly in newer growing regions such as California and eastern Oregon and Washington (Strik and Yarborough, 2005). Microsprinklers are also used occasionally for irrigation of blueberry (Haman et al., 1997). Blueberry plants irrigated by drip require about half as much water as those irrigated by sprinklers or microsprinklers (Bryla et al., 2011), but drip occasionally produces inferior fruit quality (softer fruit with lower soluble solids concentrations) (Bryla et al., 2009) and may result in root rot (Bryla and Linderman, 2007). Drip resulted in a lower cumulative yield than microsprinklers in a 7-year study on blueberry in Chile (Holzapfel et al., 2004).

Soluble $\mathrm{N}$ fertilizers such as ammonium sulfate, urea ammonium nitrate, and liquid urea are easily injected and applied through drip and microsprinkler systems and are commonly used for fertigation in vine and tree fruit crops (Bar-Yosef, 1999; Kafkafi and Tarchitsky, 2011; Schwankl et al., 1998). The practice often results in more growth and yield than equivalent rates of granular fertilizer, including in highbush blueberry (Bryla and Machado, 2011; Ehret et al., 2014; Vargas and Bryla, 2015). Some advantages of fertigation may include greater fertilizer use effi- ciency, a lower risk of "salt burn," and reduced energy and labor costs (Burt et al., 1998). However, disadvantages of fertigation may include higher fertilizer and equipment costs, increased water filtration requirements, greater risk for drip emitter plugging, and potential for soil water logging when operated during cooler and wetter months.

Recently, several manufacturers began developing modified drip products such as geotextile irrigation systems to deliver a band source of water and nutrients to the plants, rather than a point source produced by a standard drip system. A typical geotextile irrigation system has an impermeable base sheet or layer usually made of polyethylene or polypropylene, a drip line along that base, and a layer of geotextile fabric over top of the drip line. The geotextile material facilitates mass flow and disperses irrigation water and nutrients over a larger area than drip, which potentially increases the efficiency of water and fertilizer applications (i.e., less deep percolation and nutrient leaching) (Charlesworth and Muirhead, 2003; Devasirvatham, 2008; Miller et al., 2000). A wider, uniform wetting pattern may be particularly beneficial in shallow-rooted crops such as blueberry (Bryla and Strik, 2007). Furthermore, blueberry acquires primarily the ammonium $\left(\mathrm{NH}_{4}\right)$ form of $\mathrm{N}$ (Claussen and Lenz, 1999), which is immobile in soil and, when applied by fertigation, decreases with distance and depth from the drip emitter (Haynes, 1990).

The objective of the present study was to compare the effects of irrigation and fertigation with drip, microsprinklers, and geotextile tape on growth and early fruit production in northern highbush blueberry. Six cultivars were evaluated with each system, including, in order of ripening, Earliblue, Duke, Draper, Bluecrop, Elliott, and Aurora.

\section{Materials and Methods}

Study site. The study was conducted in a 0.27-ha field of northern highbush blueberry planted on 9-10 Oct. 2008 at the Oregon State University Lewis-Brown Horticultural Research Farm in Corvallis, OR (lat. $44^{\circ} 33^{\prime} 11^{\prime \prime} \mathrm{N}$, long. $123^{\circ} 12^{\prime} 55^{\prime \prime} \mathrm{W}, 68 \mathrm{~m}$ elevation). Soil at the site is a Malabon silty clay loam (fine, mixed, superactive, mesic Pachic Ultic Argixerolls). The top $30 \mathrm{~cm}$ of soil contained an average of $2.4 \%$ organic matter, $32 \mathrm{ppm} \mathrm{P}$ (Bray I), $0.3 \mathrm{~g} \cdot \mathrm{kg}^{-1} \mathrm{~K}$, $2.2 \mathrm{~g} \cdot \mathrm{kg}^{-1} \mathrm{Ca}, 0.6 \mathrm{~g} \cdot \mathrm{kg}^{-1} \mathrm{Mg}, 0.3 \mathrm{mg} \cdot \mathrm{kg}^{-1} \mathrm{~B}$, $31 \mathrm{mg} \cdot \mathrm{kg}^{-1} \mathrm{Mn}$, and $3 \mathrm{mg} \cdot \mathrm{kg}^{-1} \mathrm{Zn}$ (tested by Brookside Laboratories Inc., New Bremen, $\mathrm{OH}$ ). Soil $\mathrm{pH}$ was initially 6.2 but was adjusted to 5.5 (1:2 soil:water; Sept. 2008) by incorporating $670 \mathrm{~kg} \cdot \mathrm{ha}^{-1}$ of elemental sulfur at 6 and 12 months before planting.

The plants were obtained from a commercial nursery (Fall Creek Farm and Nursery, Lowell, OR) as 18-month-old container stock and transplanted $0.76-\mathrm{m}$ apart on raised beds (0.4-m high $\times 0.9-\mathrm{m}$ wide) at a density of 4385 plants/ha. The beds were constructed using a bed shaper and centered 3.0-m apart. 
About $8 \mathrm{~cm}$ of douglas fir (Pseudotsuga menziesii Franco) sawdust was incorporated $0.2-\mathrm{m}$ deep in each row before shaping the beds (to increase soil organic matter), and $5 \mathrm{~cm}$ was applied on top of the beds immediately after planting (as mulch). Triple super phosphate $(0 \mathrm{~N}-22 \mathrm{P}-0 \mathrm{~K})$ was mixed into the bottom of each planting hole during transplanting at rate of $4.5 \mathrm{~g} / \mathrm{plant} \mathrm{P}$. Mixed grass alleyways (1.5-m wide) were planted between the beds the following spring and, once established, were mowed every 1-2 weeks during the growing season. Weeds were controlled, as needed, using glyphosate herbicide on the base of beds and hand weeding on the top of beds. In Apr. 2011, $5 \mathrm{~cm}$ of douglas fir sawdust was reapplied to the beds. Plants were sprayed with $5.6 \mathrm{~kg} \cdot \mathrm{ha}^{-1}$ of fosetyl aluminum fungicide (Aliette WDG; Bayer Crop Science, Research Triangle Park, NC) in May 2011 for phytophthora root rot control. No insecticides or other fungicides were applied to the plants. Honeybee (Apis mellifera L.) hives were located directly adjacent to the field year-round.

Experimental design. An irrigation system was installed before planting and was designed with a manifold to accommodate 24 different treatments. The treatments were arranged in a randomized complete block design with five replications and included a combination of six cultivars (Earliblue, Duke, Draper, Bluecrop, Elliott, and Aurora) and four irrigation/fertigation treatments (fertigation at two $\mathrm{N}$ rates by drip and at one $\mathrm{N}$ rate each through geotextile tape and microsprinklers). Each treatment plot contained one row of eight plants. Only the middle six plants in the plots were used for measurements in the drip and geotextile tape treatments, and only the four middle plants (where the wetting patterns overlapped) were used for measurements in the microsprinkler treatments. The planting contained a total of 1176 plants and included 12 rows of treatment plots, plus two border plants on the end of each row, and two border rows on each side of the planting.

The drip treatments were irrigated and fertigated using a conventional drip system commonly used by many blueberry growers in western Oregon (personal observations and communication with irrigation designers).

Received for publication 18 Dec. 2014. Accepted for publication 2 Apr. 2015.

Financial support was provided by the Oregon Blueberry Commission, the Northwest Center for Small Fruits Research, and our industry contributors. We thank students and staff from the USDA-ARS Horticultural Crops Research Unit for technical assistance and D. Sullivan and P. Brown for useful comments on the manuscript.

Mention of trademark, proprietary product, or vendor does not constitute a guarantee or warranty of the product by the U.S. Dept. of Agriculture and does not imply its approval to the exclusion of other products or vendors that also may be suitable.

${ }^{1} \mathrm{PhD}$ graduate student.

${ }^{2}$ To whom reprint requests should be addressed; e-mail david.bryla@ars.usda.gov.
The system included a lateral of drip tubing (UniRam; Netafim USA, Fresno, CA) installed on each side of the row at a distance of $\approx 0.2 \mathrm{~m}$ from the base of the plants. The tubing had $2.0 \mathrm{~L} \cdot \mathrm{h}^{-1}$ pressure-compensating drip emitters integrated every $0.45 \mathrm{~m}$ and was covered with the sawdust mulch following installation. The geotextile tape treatment was fertigated using a single lateral of poly drip tape enclosed between a 10 -cm-wide layer of geotextile fabric on top and a layer of poly plastic of the same width on the bottom (4.2 L. $\mathrm{min}^{-1}$ per $100 \mathrm{~m}$ ) (BFF red; Irrigation Water Technologies America Inc., Longmont, $\mathrm{CO})$. The tape was located along the row directly near the base of the plants (on the west side). Usually, geotextile tape is installed by burying it a few cm deep; however, since blueberry is a shallow-rooted crop and produces an abundance of roots at the interface between the soil and sawdust mulch (Bryla and Strik, 2007), the tape was placed fabric side down on top of the soil surface and was covered with sawdust mulch. The microsprinkler treatments were fertigated using $22.7 \mathrm{~L} \cdot \mathrm{h}^{-1}$ hanging fan-jet emitters (DC Series; Bowsmith, Exeter, CA) located between every other plant. To avoid interference with the plants, the emitters were suspended on a trellis wire at $\approx 1.2 \mathrm{~m}$ above the initial plant canopy. The configuration produced a 2.7- to 3.0-m diameter, circular wetting pattern at operating pressures of $100-140 \mathrm{kPa}$ (Bryla et al., 2011).

Liquid urea $(20 \mathrm{~N}-0 \mathrm{P}-0 \mathrm{~K})$, a common $\mathrm{N}$ fertilizer used for fertigation in blueberry, was applied weekly to each treatment, beginning in the first week of May in 2009 and in the third week of April in 2010 and 2011, and finishing in the first week of August each year (Fig. 1). The fertilizer was injected at the manifold using adjustable 2.8-L differential pressure tanks (EZ-FLO Fertilizing Systems, Rocklin, CA). The drip treatments were fertigated with a total of 100 or $200 \mathrm{~kg} \cdot \mathrm{ha}^{-1}$ $\mathrm{N}$ per year, which, based on previous research on 'Bluecrop' blueberry, were considered low and optimum rates for fertigation by drip during establishment (Bryla and Machado, 2011). The geotextile irrigation treatment was also fertigated at the higher rate of $200 \mathrm{~kg} \cdot \mathrm{ha}^{-1} \mathrm{~N}$ per year, while microsprinkler treatments were fertigated with $280 \mathrm{~kg} \cdot \mathrm{ha}^{-1} \mathrm{~N}$ per year. Additional $\mathrm{N}$ was applied by microsprinklers to compensate for the lower application efficiency of the system $(\approx 40 \%$ of the water and fertilizer was applied between the rows and, therefore, was unavailable to the plants). Within a given fertigation/irrigation treatment, $\mathrm{N}$ was applied at the same rate to each cultivar each week. For example, each cultivar fertigated by drip at the lower $\mathrm{N}$ rate received $7.14 \mathrm{~kg} \cdot \mathrm{ha}^{-1} \mathrm{~N}$ per week in 2009 (14 weekly applications) and $6.25 \mathrm{~kg} \cdot \mathrm{ha}^{-1}$ $\mathrm{N}$ per week in 2010 and 2011 (16 weekly applications).

Plants were irrigated from June to September each year (Fig. 1). Irrigation was controlled independently in each treatment using electric solenoid valves and an automatic timer and was scheduled three to seven times per week, based on precipitation, plant size, and weekly estimates of potential and crop evapotranspiration obtained from a local Pacific Northwest Cooperative Agricultural Weather Network AgriMet weather station (http://usbr.gov/pn/agrimet) (Bryla, 2011a). All treatments were irrigated on the same day each week. Water applications were monitored using water meters (Model SRII; Sensus, Raleigh, NC) installed at the inflow of each treatment and adjusted as needed to ensure that all treatments received enough irrigation to meet $100 \%$ of estimated crop water demands each week. When possible, the plants were fertigated during scheduled irrigation events; however, additional water $\left(\approx 5 \mathrm{~mm} \cdot\right.$ week $\left.^{-1}\right)$ was needed for fertigation in April and May each year because precipitation was more than adequate for the crop during these months (Fig. 1).

Measurements. Canopy cover was estimated from digital images captured using an ADC multispectral camera (Tetracam, Chatsworth, CA) on 16-19 June and 13-14 Aug. in 2009 and on 23-25 May, 26-28 July, and 1516 Sept. in 2010 . The camera was suspended from a marked trellis wire located $\approx 2.5 \mathrm{~m}$ above the middle of each row, and the images were collected from every other plant in each plot for a total of 360 images per date. Percent live cover in the images was determined using software (Pixelwrench and Briv32) provided by the camera manufacturer (Tetracam, Chatsworth, CA). The area of the images always exceeded the width of canopy on each date. Any cover by weeds or the grass alleyway was cleaned from the images using Adobe Photoshop v. 5.0 (Adobe Systems, San Jose, CA). Live cover was converted to total percent canopy cover based on the proportion of the field covered by each image.

Plants were pruned in February each year. To encourage vegetative growth after planting, all of the flower buds were pruned from the plants for the first 2 years, and fruit were not harvested until the third year (Strik and Buller, 2005). Ripe fruit were picked by hand, beginning with 'Earliblue' and 'Duke' on 11,18 , and 25 July, 'Draper' on 25 July and 8 Aug., 'Bluecrop' on 1 and 15 Aug., 'Elliott' on 29 Aug. and 9 and 22 Sept., and 'Aurora' on 2, 13, and 28 Sept. 2011. On each date, the fruit were weighed separately from each treatment plot, and a random subsample of 100 berries was weighed to calculate the average berry weight in each plot. Any nonmarketable fruit (green, red, or damaged berries), including any small, green berries remaining after the final harvest in each cultivar, were discarded.

Leaf samples were collected during the first week of August each year and analyzed for N. Six recently mature leaves were removed and pooled together from each of the center four (microsprinklers) or six (drip and geotextile tape) plants in each plot, ovendried at $70{ }^{\circ} \mathrm{C}$, ground, and analyzed for total $\mathrm{N}$ using a combustion analyzer (model CNS2000; LECO Corp., St. Joseph, MI). Each sample was also analyzed for $\mathrm{P}, \mathrm{K}, \mathrm{Ca}, \mathrm{Mg}, \mathrm{S}$, $\mathrm{B}, \mathrm{Cu}, \mathrm{Mn}$, and $\mathrm{Zn}$ (Brookside Laboratories Inc.) during the second year after planting. 

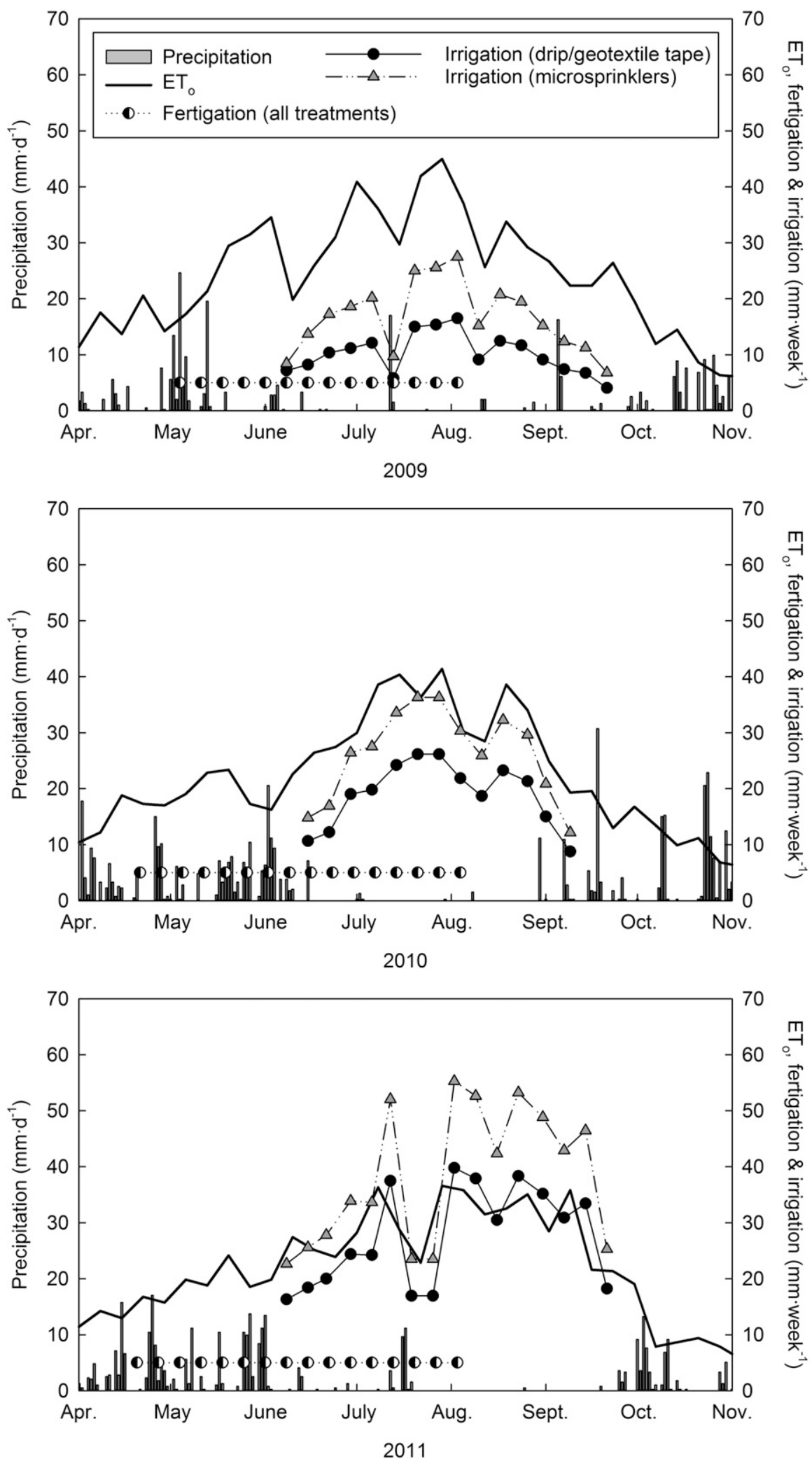

Fig. 1. Precipitation, potential evapotranspiration $\left(\mathrm{ET}_{\mathrm{o}}\right)$, and water applied by fertigation and irrigation to northern highbush blueberry during the first 3 years after planting (2009-11). The plants were fertigated once a week (using $5 \mathrm{~mm}$ of water on each event) and irrigated one to five times per week, as needed, through drip, geotextile, or microsprinkler irrigation systems. Irrigation was adjusted for plant size and irrigation system efficiency following the procedures outlined in Holzapfel et al. (2004).

Leaf B was the only nutrient below the recommended concentration for highbush blueberry ( $\leq 30$ ppm B) (Hart et al., 2006). The plants were sprayed with disodium octaborate tetrahydrate (Solubor; U.S. Borax Inc., Greenwood Village, CO) fertilizer (20\% B) the following spring at rate of $4.8 \mathrm{~g} \cdot \mathrm{L}^{-1}$ per hectare.
A number of 'Draper' plants had stunted growth and poor leaf color (i.e., yellowing and premature reddening) beginning in the second year after planting (2010). Symptoms were consistent with phytophthora root rot (Caruso and Ramsdell, 1995). Therefore, roots were sampled from three healthy and five unhealthy plants (one from each replicate treatment plot) and assayed for Phytophthora by removing a subsample of soil $\left(5 \mathrm{~cm}^{2} \times\right.$ $15 \mathrm{~cm}$ deep) located within $15 \mathrm{~cm}$ from the base of the plants. Two methods were used to isolate and identify the pathogen using both roots and soil from the samples. Roots were washed free of the soil in running tap water and then surface disinfected for $2 \mathrm{~min}$ in $70 \%$ ethanol solution, before plating 10 , 1-cm-long root segments per plant on poly ADP ribose polymerase (PARP), a semiselective medium for Pythiaceous species (Kannwischer and Mitchell, 1978). Soil was baited with leaf disks of Rhododendron 'Unique' (Weiland, 2011). Briefly, $15 \mathrm{~mL}$ of soil from each plant was placed into a $150 \mathrm{~mL}$ waxed-paper cup. A second paper cup, with the bottom cut out and replaced with a double layer of cheesecloth, was positioned over the soil sample and filled with $50 \mathrm{~mL}$ of distilled water. Twelve 5-mm-diameter leaf disks were then floated on the water surface in each cup for $2 \mathrm{~d}$ before plating them on PARP. The plates were incubated in the dark at $20^{\circ} \mathrm{C}$ and then examined daily for colonies of Phytophthora species for at least $7 \mathrm{~d}$. Isolates were identified as $P$. cinnamomi by morphological characteristics, according to the taxonomic keys of Stamps et al. (1990), and confirmed by sequencing (Macrogen, Korea) the internal transcriber spacer region of each isolate and comparing the resultant sequence to that published by Cooke and Duncan (1997). Plants displaying symptoms of the disease were counted from the six middle plants in each plot on 11 Nov. 2010. 'Draper' was the only cultivar with symptoms.

Statistical analysis. All data were analyzed by ANOVA using the PROC MIXED procedure in SAS (Version 9.3; SAS Institute Inc., Cary, NC). Means were separated at the 0.05 level using the Tukey-Kramer honestly significant difference test. To account for the heterogeneity structure in each dataset, cultivars with highly variable values such as 'Draper' were assigned independent variance parameters (Little et al., 2006). The incidence of root rot symptoms in 'Draper' plants was evaluated in 2010 by the $\chi^{2}$ test of independence using the PROC FREQ procedure in SAS to determine if symptoms were independent of fertigation and irrigation method. 'Draper' was subsequently subsampled between healthy (no root rot symptoms) and unhealthy plants the following year, and only the healthy plants were included in the analysis of leaf $\mathrm{N}$ and fruit production in year 3 (2011).

\section{Results}

Canopy cover. Canopy cover in each cultivar increased from $\leq 8 \%$ in June 2009 
(year 1) to as much as $58 \%$ to $89 \%$ by Sept. 2010 (Fig. 2). On average, canopy cover was greatest with geotextile tape $\left(\bar{X}_{\text {Aug. }}=17 \%\right)$ and lowest with microsprinklers $\left(\bar{X}_{\text {Aug. }}=8 \%\right)$ or drip at the lower $\mathrm{N}$ rate $\left(\bar{X}_{\text {Aug. }}=9 \%\right)$ during the first year after planting, and was greatest with drip at the higher $\mathrm{N}$ rate $\left(\bar{X}_{\text {Sept. }}=80 \%\right)$ and lowest with microsprinklers $\left(X_{\text {Sept. }}=58 \%\right)$ the following year. Significant interactions in May $(P=0.0108)$ and Sept. $2010(P=0.0186)$ indicate that the plant response to the different irrigation systems and $\mathrm{N}$ rates differed among the cultivars. For example, while four of the cultivars had more canopy cover with drip or geotextile tape than with microsprinklers in Sept. 2010, percent cover in 'Duke' only differed at that point between drip at the higher $\mathrm{N}$ rate and microsprinklers, and 'Draper' was similar among each system and $\mathrm{N}$ rate (Fig. 2).
Phytophthora root rot. Most of the plants in the study were healthy and vigorous. However, as mentioned, a number of the 'Draper' plants had poor growth the second year and were infected by $P$. cinnamomi. A $\chi^{2}$ test revealed that phytophthora root rot symptoms in this cultivar were dependent on the irrigation system $(P=0.0473)$. The use of geotextile tape resulted in about twice as many plants with symptoms of root rot than either drip or microsprinklers (Table 1).

Leaf $N$ concentration. The concentration of $\mathrm{N}$ in the leaves varied among the treatments each year and resulted in significant interactions $(P \leq 0.05)$ (Fig. 3). For example, during the first year after planting (2009), leaf $\mathrm{N}$ was similar among each system and $\mathrm{N}$ rate in 'Bluecrop', as well as with drip at either $\mathrm{N}$ rate in 'Elliott', and only differed between geotextile tape and microsprinklers in 'Elliott' and 'Aurora'. The following year, leaf $\mathrm{N}$ was similar between drip (regardless of $\mathrm{N}$ rate) and geotextile tape in each cultivar and only differed between the two $\mathrm{N}$ rates with drip in 'Earliblue' and 'Draper' and only differed between geotextile tape and microsprinklers in 'Bluecrop'. By the third year, leaf $\mathrm{N}$ continued to be similar among the irrigation systems and $\mathrm{N}$ rates in 'Duke' and 'Elliott', as well as in 'Aurora' at that point, and only differed between the two drip treatments in 'Earliblue', 'Draper', and 'Bluecrop', and between geotextile tape and microsprinklers in 'Earliblue'.

In most of the cultivars, leaf $\mathrm{N}$ concentration was within or slightly below the range considered "normal" for blueberry $(1.76 \%$ to $2.00 \% \mathrm{~N}$ ) (Hart et al., 2006) when plants were

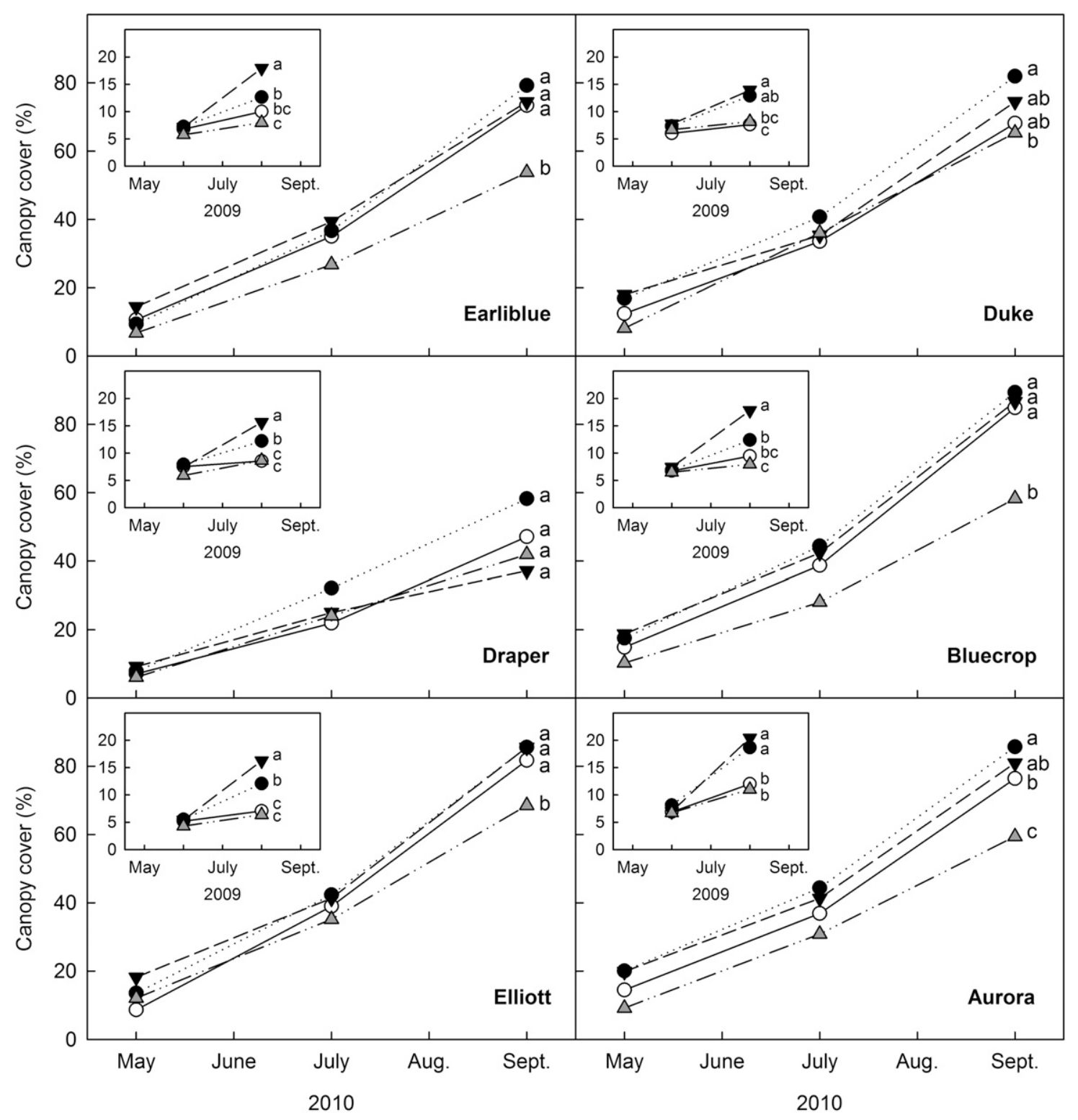

Fig. 2. Canopy cover of early- ('Earliblue' and 'Duke'), mid- ('Draper' and 'Bluecrop'), and late-season ('Elliott' and 'Aurora') cultivars of northern highbush

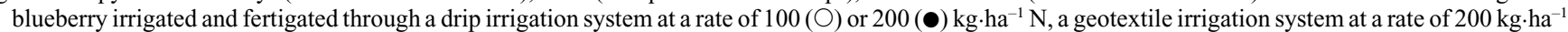
$\mathrm{N}(\boldsymbol{\nabla})$, or a microsprinkler system at a rate of $280 \mathrm{~kg} \cdot \mathrm{ha}^{-1} \mathrm{~N}(\triangle)$ during the first (2009; insets) and second year (2010) after planting. Each symbol represents the mean of five replicates, and means with different letters in Aug. 2009 and Sept. 2010 are significantly different at $P \leq 0.05$, according to Tukey's honestly significant difference test. 
Table 1. Percentage of unhealthy plants displaying symptoms of phytophthora root rot in 'Draper' blueberry as influenced by the irrigation system and $\mathrm{N}$ rate.

\begin{tabular}{lc}
\hline \multicolumn{1}{c}{ Irrigation system $/ \mathrm{N}$ rate } & \begin{tabular}{c} 
Unhealthy $_{\text {plants }^{2}(\%)}$ \\
\hline Drip $\left(100 \mathrm{~kg} \cdot \mathrm{ha}^{-1} \mathrm{~N}\right)$
\end{tabular} \\
Drip $\left(200 \mathrm{~kg} \cdot \mathrm{ha}^{-1} \mathrm{~N}\right)$ & 23 \\
Geotextile tape $\left(200 \mathrm{~kg} \cdot \mathrm{ha}^{-1} \mathrm{~N}\right)$ & 50 \\
Microsprinkler $\left(280 \mathrm{~kg} \cdot \mathrm{ha}^{-1} \mathrm{~N}\right)$ & 27
\end{tabular}

Healthy vs. unhealthy plants

$\chi^{2}=7.93 \quad \mathrm{df}=3 \quad P=0.0473$

${ }^{\text {z Six plants from each treatment plot were evaluated }}$ for root rot symptoms $(n=30)$. Symptoms included stunted growth, pale yellow to reddish leaves, marginal leaf necrosis, and premature defoliation.

irrigated and fertigated by drip at the higher $\mathrm{N}$ rate or by geotextile tape, but was often "deficient" $(<1.50 \% \mathrm{~N})$ with drip at the lower $\mathrm{N}$ rate or with microsprinklers (Fig. 3). Leaf $\mathrm{N}$ was also lower and more often deficient in $2010\left(\bar{X}_{\mathrm{All}}=1.48 \%\right)$ than in 2009 or $2011\left(\bar{X}_{\mathrm{All}}=1.65 \%\right.$ and $1.62 \% \mathrm{~N}$, respectively). This was particularly the case in 'Draper,' which, as mentioned, was hampered by root rot in 2010 (Table 1). Leaves were only sampled from healthy 'Draper' plants the following year (2011). Therefore, leaf $\mathrm{N}$ concentration in the cultivar was much higher in 2011 than in the previous year (1.39\% in 2010 vs. $1.75 \%$ in 2011$)$.

Early fruit production. Marketable yield differed among irrigation systems and $\mathrm{N}$ rates in 2011 (the first year of fruit production) and, on average, was $31 \%$ greater with geotextile tape or drip at the higher $\mathrm{N}$ rate than with microsprinklers (Table 2). However, yield was similar with either $\mathrm{N}$ rate by drip, and similar between drip at the lower $\mathrm{N}$ rate and microsprinklers. 'Elliott' produced the highest yield among the cultivars, while 'Earliblue' produced the lowest yield (Table 2).

Berry weight also differed among the cultivars, but unlike yield, it was similar among the irrigation systems and $\mathrm{N}$ rates (Table 2). In most cases, the appearance of the fruit was excellent and suitable for fresh market. However, many of the berries that were harvested from the plants with microsprinklers were covered with white salt deposits from the fertilizer.

\section{Discussion}

Initially, during the first year after planting, geotextile tape resulted in larger plants than drip in four out of six cultivars, including Earliblue, Draper, Bluecrop, and Elliott, while microsprinklers produced the smallest plants in each cultivar. More growth with geotextile tape could have been a result of the even distribution of water and fertilizer along the row but was more likely because of the position of the irrigation lines. Since $\mathrm{NH}_{4}-\mathrm{N}$ is relatively immobile in soil, application of $\mathrm{N}$ by drip may have positioned the fertilizer too far from the roots of the young plants (Haynes, 1990). However, increasing the $\mathrm{N}$ rate with drip from 100 to $200 \mathrm{~kg} \cdot \mathrm{ha}^{-1} \mathrm{~N}$

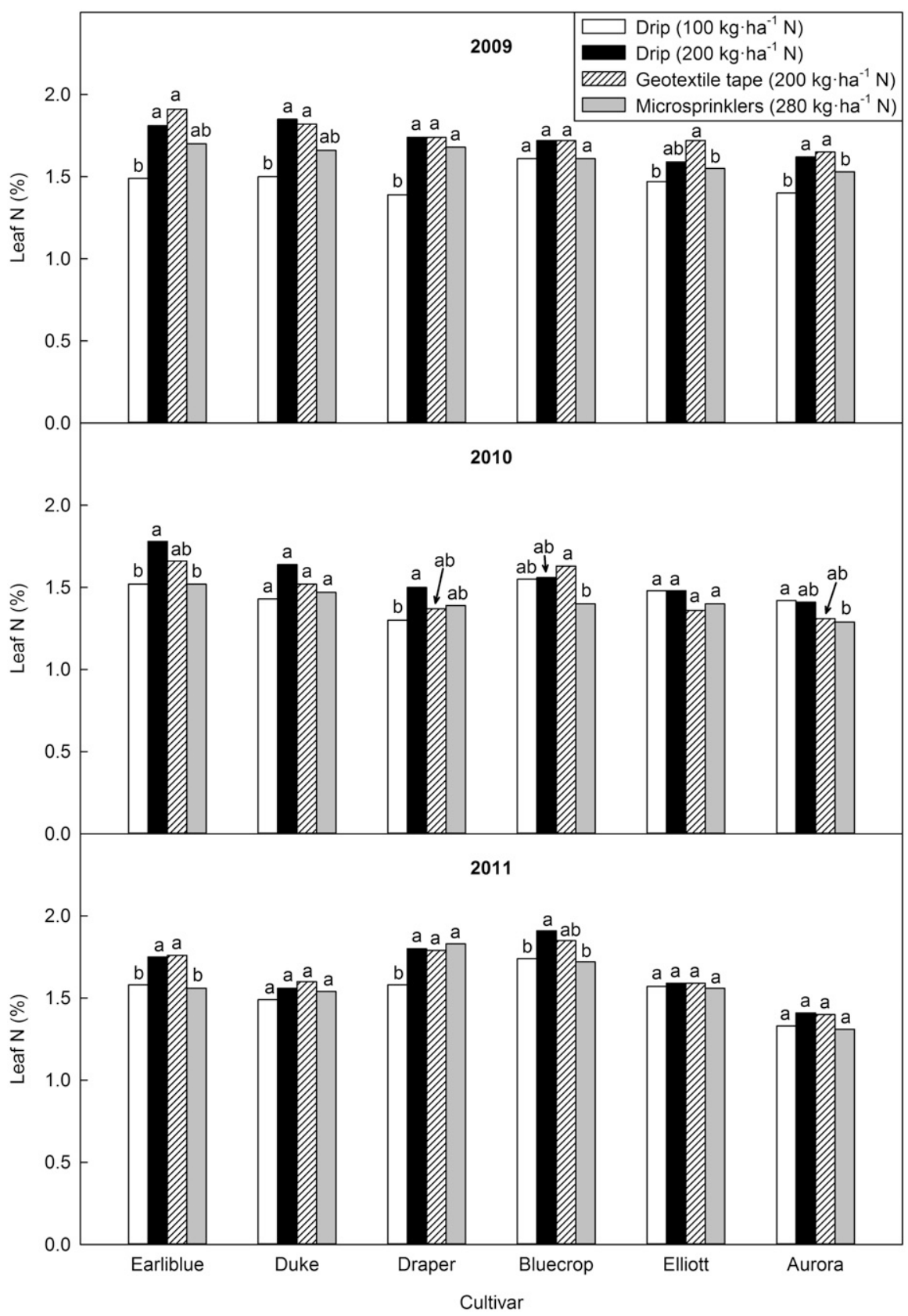

Fig. 3. Leaf $\mathrm{N}$ concentrations of early-season ('Earliblue' and 'Duke'), mid-season ('Draper' and 'Bluecrop'), and late-season ('Elliott' and 'Aurora') cultivars of northern highbush blueberry during the first 3 years after planting (2009-11). Each cultivar was irrigated and fertigated through a drip irrigation system at a rate of 100 or $200 \mathrm{~kg} \cdot \mathrm{ha}^{-1} \mathrm{~N}$, a geotextile irrigation system at a rate of $200 \mathrm{~kg} \cdot \mathrm{ha}^{-1}$ $\mathrm{N}$, or a microsprinkler system at a rate of $280 \mathrm{~kg} \cdot \mathrm{ha}^{-1} \mathrm{~N}$. Each bar represents the mean of five replicates, and different letters above the bars indicate that means within a cultivar are significantly different at $P \leq 0.05$, according to Tukey's honestly significant difference test.

improved leaf $\mathrm{N}$ and plant growth considerably the first year. Fertigation with microsprinklers, on the other hand, appeared to be less $\mathrm{N}$ efficient than drip.

By the second year, plant size was similar between drip at the higher $\mathrm{N}$ rate and geotextile tape in each cultivar, as well as between the drip treatments fertigated with low and high $\mathrm{N}$ rates in all but 'Aurora'. Yield was also similar among these treatments the following year. While it was not measured in the study, the root systems of the plants were likely much larger by the beginning of the second season than in the previous year, and roots were probably concentrated near the drip emitters (Bryla, 2011b). If so, more of the $\mathrm{N}$ applied through the drip system would have been available for root uptake and, therefore, would explain why less $\mathrm{N}$ (i.e., $100 \mathrm{~kg} \cdot \mathrm{ha}^{-1}$ ) was needed in plants fertigated by drip during the latter 2 years of the study. Only $67-93 \mathrm{~kg} \cdot \mathrm{ha}^{-1} \mathrm{~N}$ was required for fertigation by drip to maximize yield in a mature field of 'Bluecrop' blueberry (Vargas and Bryla, 2015).

Microsprinklers continued to result in the smallest plants in most cultivars in the second year and, on average, produced lower yield 
Table 2. Effects of irrigation system, $\mathrm{N}$ rate, and cultivar on yield and berry weight during the first year of fruit production (year 3 ) in highbush blueberry.

\begin{tabular}{lcc}
\hline Treatment & Yield (kg/plant) & Berry wt $^{z}(\mathrm{~g})$ \\
\hline Irrigation system/N rate & & \\
Drip $\left(100 \mathrm{~kg} \cdot \mathrm{ha}^{-1} \mathrm{~N}\right)$ & $1.40 \mathrm{ab}^{\mathrm{y}}$ & 2.04 \\
Drip $\left(200 \mathrm{~kg} \cdot \mathrm{ha}^{-1} \mathrm{~N}\right)$ & $1.54 \mathrm{a}$ & 1.98 \\
Geotextile $\left(200 \mathrm{~kg} \cdot \mathrm{ha}^{-1} \mathrm{~N}\right)$ & $1.57 \mathrm{a}$ & 1.98 \\
Microsprinkler $\left(280 \mathrm{~kg} \cdot \mathrm{ha}^{-1} \mathrm{~N}\right)$ & $1.19 \mathrm{~b}$ & 2.02 \\
Significance & 0.0003 & $\mathrm{NS}$ \\
Cultivar & & \\
Earliblue & $0.72 \mathrm{~d}$ & $1.94 \mathrm{~b}$ \\
Duke & $1.30 \mathrm{c}$ & $2.07 \mathrm{ab}$ \\
Draper & $1.27 \mathrm{c}$ & $1.93 \mathrm{~b}$ \\
Bluecrop & $1.65 \mathrm{~b}$ & $2.13 \mathrm{a}$ \\
Elliott & $2.12 \mathrm{a}$ & $1.85 \mathrm{c}$ \\
Aurora & $1.48 \mathrm{bc}$ & $2.12 \mathrm{a}$ \\
Significance & $<0.0001$ & $<0.0001$ \\
Interaction & & \\
Irrigation system $/ \mathrm{N}$ rate $\times$ cultivar & $\mathrm{NS}$ & $\mathrm{NS}$ \\
\hline
\end{tabular}

${ }^{2}$ Berry weight was averaged over each harvest, and the mean was weighted based on yield.

${ }^{\mathrm{y}}$ Means $(n=5)$ followed by a different letter within a column are significantly different at $P \leq 0.05$, according to Tukey's honestly significant difference test.

$\mathrm{NS}=$ nonsignificant.

than drip at the higher $\mathrm{N}$ rate and geotextile tape the following year. This indicates that the efficiency of $\mathrm{N}$ fertigation through the microsprinklers was likely lower than the $40 \%$ loss estimated based on bed coverage. The fertilizer $\mathrm{N}$ was not only spread over a much larger area with microsprinklers than with the other systems but also applied on top of the sawdust mulch and, therefore, probably partially immobilized by microbial decomposition (Jackson et al., 2009). Potential strategies for increasing the efficiency of the microsprinklers may include the use of more emitters per row, emitters with a lower flow rate or a narrower wetting pattern, a lower emitter placement height, and the use of "top hats" (Bowsmith), which affix to the top of the emitters and restrict the spray diameter.

The $\mathrm{N}$ rates used in the present study were much higher than those typically recommended for granular fertilizers in highbush blueberry. For example, in Oregon, Hart et al. (2006) recommend applying $17-26 \mathrm{~g} /$ plant of granular $\mathrm{N}$ to a planting without sawdust mulch during the first 4 years after planting. At the plant spacing used in the present study, this would be equivalent to $\approx 60-90 \mathrm{~kg} \cdot \mathrm{ha}^{-1} \mathrm{~N}$ per year. Higher $\mathrm{N}$ rates are recommended initially for fertigation because of low application efficiency in young plantings (Bryla and Machado, 2011). Even when a drip line is located near the base of the plants, over half of the emitters in a standard $0.30-0.45 \mathrm{~m}$ spacing configuration will be located between the plants and outside of the root zone during the first year after planting. Therefore, much of the $\mathrm{NH}_{4}-\mathrm{N}$ will be unavailable to the plants. Most of this unavailable $\mathrm{N}$ will convert to $\mathrm{NO}_{3}-\mathrm{N}$ and eventually leach from the soil with rain and irrigation (Bryla et al., 2010).

In terms of yield, the most efficient system used in the study was drip at the lower $\mathrm{N}$ rate $\left(100 \mathrm{~kg} \cdot \mathrm{ha}^{-1} \mathrm{~N}\right)$. The total amount of $\mathrm{N}$ required to produce $1 \mathrm{~kg}$ of fruit in the treatment was roughly half as much as geotextile tape or drip at the higher $\mathrm{N}$ rate. However, leaf $\mathrm{N}$ was below normal each year at the lower $\mathrm{N}$ rate, especially in the higher yielding cultivars, 'Elliott' and 'Aurora'. This suggests that $\mathrm{N}$ standards could be lower with fertigation than with granular fertilizer (Hart et al., 2006). Yield ranged from an average of $3.1 \mathrm{t} \cdot \mathrm{ha}^{-1}$ in the early-season cultivar, 'Earliblue', to $9.1 \mathrm{t} \cdot \mathrm{ha}^{-1}$ in the lateseason cultivar, Elliott, which is comparable to commercial fields of this age (B.C. Strik, personal communication).

While most plants were healthy in the study, 'Draper' developed root rot symptoms in the second year and were found to be infected by $P$. cinnamomi, a highly virulent root rot pathogen of highbush blueberry that is present in most growing regions worldwide (Strik and Yarborough, 2005). In a survey of 55 commercial blueberry fields in Oregon, $P$. cinnamomi was detected in $24 \%$ of the fields (Bryla et al., 2008). Susceptibility to the pathogen varies among cultivars and increases under wet soil conditions. Yeo (2014) recently exposed 18 cultivars and three advanced selections of highbush blueberry to $P$. cinnamomi under greenhouse conditions and determined that 'Draper' was among the most susceptible cultivars evaluated. In our study, disease incidence was nearly double when plants were irrigated and fertigated with the geotextile tape. The tape likely resulted in wetter soil conditions near the base of the plants and, consequently, was more conducive to root infection. Bryla and Linderman (2007) found similar results when drip lines were placed near the base of the plants in 'Duke' blueberry.

\section{Conclusion}

Although leaf $\mathrm{N}$ was lower than the recommended standard, blueberry growth and yield was most efficient when the plants were irrigated and fertigated by drip at the lower $\mathrm{N}$ rate $\left(100 \mathrm{~kg} \cdot \mathrm{ha}^{-1} \mathrm{~N}\right)$. While geotextile tape was also effective, particularly during the first year after planting, it was more expensive and produced more or less the same amount of growth and yield as drip the following 2 years. Geotextile tape also increased the incidence of root rot in 'Draper'. Microsprinklers, on the other hand, reduced yield and fruit quality (white deposits on the berries) in each cultivar and resulted in much lower $\mathrm{N}$ efficiency than the other treatments. Installing the microsprinklers at a lower height or on the ground may help circumvent these problems. While drip was clearly the best system for fertigation of northern highbush blueberry in the present study, the alternative systems could have advantages in sandier soils where lateral movement of water and nutrients is more limited. Therefore, further testing of these systems in other soil types is warranted.

\section{Literature Cited}

Bar-Yosef, B. 1999. Advances in fertigation. Adv. Agron. 65:1-77.

Bryla, D.R. 2011a. Crop evapotranspiration and irrigation scheduling in blueberry, p. 167-186. In: G. Gerosa (ed.). Evapotranspiration-from measurements to agricultural and environmental applications. InTech, Rijeka, Croatia.

Bryla, D.R. 2011b. Application of the "4R" nutrient stewardship concept to horticultural crops: Getting nutrients in the "right" place. HortTechnology 21:674-682.

Bryla, D.R. and R.G. Linderman. 2007. Implications of irrigation method and amount of water application on Phytophthora and Pythium infection and severity of root rot in highbush blueberry. HortScience 42:1463-1467.

Bryla, D.R. and R.M.A. Machado. 2011. Comparative effects of nitrogen fertigation and granular fertilizer application on growth and availability of soil nitrogen during establishment of highbush blueberry. Front. Plant Sci. 2:46.

Bryla, D.R. and B.C. Strik. 2007. Effects of cultivar and plant spacing on the seasonal water requirements of highbush blueberry. J. Amer. Soc. Hort. Sci. 132:270-277.

Bryla, D.R., J.L. Gartung, and B.C. Strik. 2011. Evaluation of irrigation methods for highbush blueberry-I. Growth and water requirements of young plants. HortScience 46:95-101.

Bryla, D.R., R.G. Linderman, and W.Q. Yang. 2008. Incidence of Phytophthora and Pythium infection and the relation to cultural conditions in commercial blueberry fields. HortScience 43:260-263.

Bryla, D.R., A.D. Shireman, and R.M.A. Machado. 2010. Effects of method and level of nitrogen fertilizer application on soil $\mathrm{pH}$, electrical conductivity, and availability of ammonium and nitrate in blueberry. Acta Hort. 868:95101.

Bryla, D.R., B. Yorgey, and A.D. Shireman. 2009. Irrigation management effects on yield and fruit quality of highbush blueberry. Acta Hort. 810:649-656.

Burt, C., K. O'Connor, and T. Ruehr. 1998. Fertigation. Irr. Training Res. Ctr., Calif. Polytechnic St. Univ., San Luis Obispo, CA.

Caruso, F.L. and D.C. Ramsdell. 1995. Compendium of blueberry and cranberry diseases. APS Press, St. Paul, MN.

Charlesworth, P.B. and W.A. Muirhead. 2003. Crop establishment using subsurface drip irrigation: A comparison of point and area sources. Irrig. Sci. 22:171-176.

Claussen, W. and F. Lenz. 1999. Effect of ammonium or nitrate nutrition on net photosynthesis, growth, and activity of the enzymes nitrate 
reductase and glutamine synthetase in blueberry, raspberry and strawberry. Plant Soil 208:95-102.

Cooke, D.E.L. and J.M. Duncan. 1997. Phylogenetic analysis of Phytophthora species based on ITS1 and ITS2 sequences of the ribosomal RNA gene repeat. Mycol. Res. 101:667-677.

Devasirvatham, V. 2008. Improved lettuce establishment by subsurface drip irrigation. Univ. Western Sydney, Sydney, Australia, MS Thesis.

Ehret, D.L., B. Frey, T.A. Forge, T. Helmer, D.R. Bryla, and B.J. Zebarth. 2014. Effects of nitrogen rate and application method on early production and fruit quality in highbush blueberry. Can. J. Plant Sci. 94:1165-1179.

Haman, D.Z., A.G. Smajstria, R.T. Pritchard, and P.M. Lyrene. 1997. Response of young blueberry plants to irrigation in Florida. HortScience 32:1194-1196.

Hart, J., B. Strik, L. White, and W. Yang. 2006. Publ. EM 8918. Nutrient management for blueberries in Oregon. Ore. State Univ. Ext. Serv., Corvallis, OR.

Haynes, R.J. 1990. Movement and transformations of fertigated nitrogen below trickle emitters and their effects on $\mathrm{pH}$ in the wetted soil volume. Fert. Res. 23:105-112.
Holzapfel, E.A., R.F. Hepp, and M.A. Marino. 2004. Effect of irrigation on fruit production in blueberry. Agr. Water Mgt. 67:173-184.

Jackson, B.E., R.D. Wright, and M.M. Alley. 2009. Comparison of fertilizer nitrogen availability, nitrogen immobilization, substrate carbon dioxide efflux, and nutrient leaching in peat-lite, pine bark, and pine tree substrates. HortScience 44:781-790.

Kafkafi, U. and J. Tarchitsky. 2011. Fertigation. A tool for efficient fertilizer and water management. Intl. Fert. Ind. Assn., Paris, France and Intl. Potash Inst., Horgen, Switzerland.

Kannwischer, M.E. and D.J. Mitchell. 1978. The influence of a fungicide on the epidemiology of black shank of tobacco. Phytopathology 68:1760-1765.

Little, T.D., J.A. Bovaird, and K.F. Widaman. 2006. On the merits of orthogonalizing powered and product terms: Implications for modeling interactions among latent variables. Struct. Equ. Modeling 13:497-519.

Miller, M.L., P.B. Charlesworth, A. Katupitiya, and W.A. Muirhead. 2000. A comparison of a new subsurface drip irrigation system with a conventional SDI system using pulsed and continuous irrigation management. Proc. Natl. Conf. Irr. Assn., Australia, May 23-25, Melbourne, Australia.
Schwankl, L., B. Hanson, and T. Prichard. 1998. Micro-irrigation of trees and vines: A handbook for water managers. Publ. 3378. Div. Agr. Natural Resources, Univ. Calif., Oakland, CA.

Stamps, D.J., G.M. Waterhouse, F.J. Newhook, and G.S. Hall. 1990. Revised tabular key to the species of Phytophthora. CAB Intl. Mycol. Inst., Mycol. Paper 162.

Strik, B.C. and G. Buller. 2005. The impact of early cropping on subsequent growth and yield of highbush blueberry in the establishment years at two planting densities is cultivar dependant. HortScience 40:1998-2001.

Strik, B.C. and D. Yarborough. 2005. Blueberry production trends in North America, 1992 to 2003, and predictions for growth. HortTechnology 15:391-398.

Vargas, O.L. and D.R. Bryla. 2015. Growth and fruit production of highbush blueberry fertilized with ammonium sulfate and urea applied by fertigation or as granular fertilizer. HortScience 50:479-485.

Weiland, J.E. 2011. Influence of isolation method on recovery of Pythium species from forest nursery soils in Oregon and Washington. Plant Dis. 95:547-553.

Yeo, J.R. 2014. Cultural controls for suppressing Phytophthora cinnamomi root rot of blueberry. Ore. State Univ., Corvallis, $\mathrm{PhD}$ Diss. 